\title{
Quercetin Glucoside Profiling of Fresh Onion (Allium cepa) and Aged Black Onion Using HPLC-ESI/MS/MS
}

\author{
Dong-Min Chung ${ }^{1}$, Sun Hwa Kwon ${ }^{1}$, Young Chul Chung ${ }^{2}$ and Hyo Kon Chun * \\ ${ }^{1}$ Bioindustrial Process Center, Jeonbuk Branch Institute, Korea Research Institute of Bioscience and Biotechnology, Jeonbuk 580-185, Koreá \\ ${ }^{2}$ Department of Food Nutrition, International University of Korea, Jinju 660-750, Korea
}

Received December 9, 2010/Accepted March 14, 2011

\begin{abstract}
Quercetin is a major flavonoid present in onions, which acts as an antioxidant. Quercetin exists both as a free compound and conjugated with carbohydrates, primarily as glucosides in onion. Aged black onion was made through a 30 day aging process in which the onions were kept in an environment of $60^{\circ} \mathrm{C}$ and high humidity (90\% RH). Quercetin and quercetin glucosides were assayed in onion bulbs before and after the aging process, using high performance liquid chromatography-electrospray ion trap mass spectrometry (HPLC-ESI/MS/MS). Quercetin mono- and diglucosides were identified in fresh onion bulbs, whereas quercetin aglycone was the only form present in aged black onion bulbs. These findings indicate that the quercetin mono- and di-glucosides present in fresh onions undergo complete deglycosylation during the aging process. Such profiling will provide a rapid method that can be used to assess changes in the two major quercetin glycosides during the aging process of onion bulbs.
\end{abstract}

Key words : Allium cepa, flavonol, quercetin, quercetin glucoside, HPLC-ESI/MS/MS

\section{Introduction}

Quercetin is the major flavonoid present in the onion (Allium cepa). The chemical is found predominantly as quercetin 3,4'-O-diglucoside and 4'-O-monoglucoside, although several other forms of mono- and diglucoside conjugates have been reported. Amounts of this flavonoid in onions vary with bulb color and type, being mostly found in the outer skins and rings [1]. Such compounds exhibit a variety of biological activities, including cardiovascular protection, and anti-cancer, anti-inflammatory, and antioxidant activities [2,5].

The quercetin compounds play a key role in the health effects of dietary quercetin [9]. However, the question whether quercetin aglycone or its glucosides are available in the systemic circulation after consumption of quercetin or quercetin-rich food products in humans is still a matter of dispute [10]. As the biological activity of these compounds is dependent on the nature and position of the glycosylation, it is important to chemically characterize the quercetin compounds. Among the analytical methods used to analyze such compounds, HPLC with UV detection, HPLC with fluorescent detection, $\mathrm{LC}-\mathrm{MS}$, and $\mathrm{LC}-\mathrm{MS} / \mathrm{MS}$ have been employed $[3,4,6]$. Particularly, LC-MS/MS may be a very sensi-

*Corresponding author

Tel: 82-63-570-5120; Fax: 82-63-570-5109

E-mail: hkchun@kribb.re.kr tive and reliable method for the required analysis.

Since ancient times, onions have been used as food, spice, and medicinal plants in many cultures. Because of their distinct flavor and aroma, onions are commonly consumed alone or in prepared foods after being subjected to a wide variety of processing methods [8]. The aging process is spontaneous fermentation for $30-60$ days at $60-80^{\circ} \mathrm{C}$ and high humidity (90\% RH). Using this process, unstable and highly odorous compounds of garlic and onion can be converted into stable and odorless compounds with black color. Recently, the biological effects of aged black garlic have been studied [7]. Although many reports on onion have been studied, there is little information on aged black onion.

In this present study, we utilized the HPLC-ESI/MS/MS method to determine changes in the composition of quercetin glycosides after aging process of fresh onions bulb.

\section{Materials and Methods}

\section{Chemicals}

All chemicals and solvents were purchased from Sigma-Aldrich (St, Louis, Mo., USA). Quercetin compounds (Quercetin-3,4'-O- $\beta$-glucoside, quercetin-4'-O- $\beta$-glucoside and quercetin) were purchase from Extrasynthese (Genay, France). 


\section{Plant material}

Onions were purchased from Jeongeup agricultural market in Korea. Aged black onions were prepared by incubating fresh onions at $60^{\circ} \mathrm{C}$ under $90 \%$ humidity for 1 month. Both fresh and aged onions were frozen and freeze dried. This material was ground to a fine powder and stored at $-20^{\circ} \mathrm{C}$. Each gram of powdered sample was subsequently extracted three times, each time with $10 \mathrm{ml}$ of $100 \%$ ethanol for $6 \mathrm{hr}$. The aqueous filtered ethanolic fraction was collected, and residual ethanol was evaporated by fast vacuum drying. The dried extract was redissolved in 70\% (v/v) ethanol to a final volume of $1 \mathrm{ml}$, and samples were stored at $-70^{\circ} \mathrm{C}$ until analysis.

\section{HPLC-ESI/MS/MS analysis}

HPLC analyses were performed using an Agilent series
1200 quaternary solvent delivery system, a cooled autosampler $\left(4^{\circ} \mathrm{C}\right)$, and a photodiode array detector (Agilent; Waldron, Germany). Samples, passed through a $0.45 \mu \mathrm{m}$ filter just prior to HPLC injection, were separated on a YMC ODS column $(4.5 \times 250 \mathrm{~mm}, 5 \mu \mathrm{m}$ particle size $)$ maintained at $30^{\circ} \mathrm{C}$. The mobile phase consisted of $(\mathrm{A}) 0.1 \%(\mathrm{v} / \mathrm{v})$ formic acid in water, and, (B) $0.1 \%(\mathrm{v} / \mathrm{v})$ formic acid in methanol, with a gradient consisting of 5\% B (0-5 min), 5-80\% B (5-30 $\mathrm{min}$ ), $80 \% \mathrm{~B}(30-50 \mathrm{~min}$ ), and $80 \%-5 \% \mathrm{~B}$ (50-60 min), at a flow rate of $0.5 \mathrm{ml} / \mathrm{min}$. Eluate was monitored at $210 \mathrm{~nm}$, $254 \mathrm{~nm}, 280 \mathrm{~nm}$, and $370 \mathrm{~nm}$. Data were recorded at 254 $\mathrm{nm}$. The quercetin compounds were used for identification and quantification as a standard.

Mass analyses were performed using an electrospray ionization source (ESI; Bruker Daltonics, Bermen, Germany) connected to an ion trap mass spectrometer (MS). MS operat-

(a)

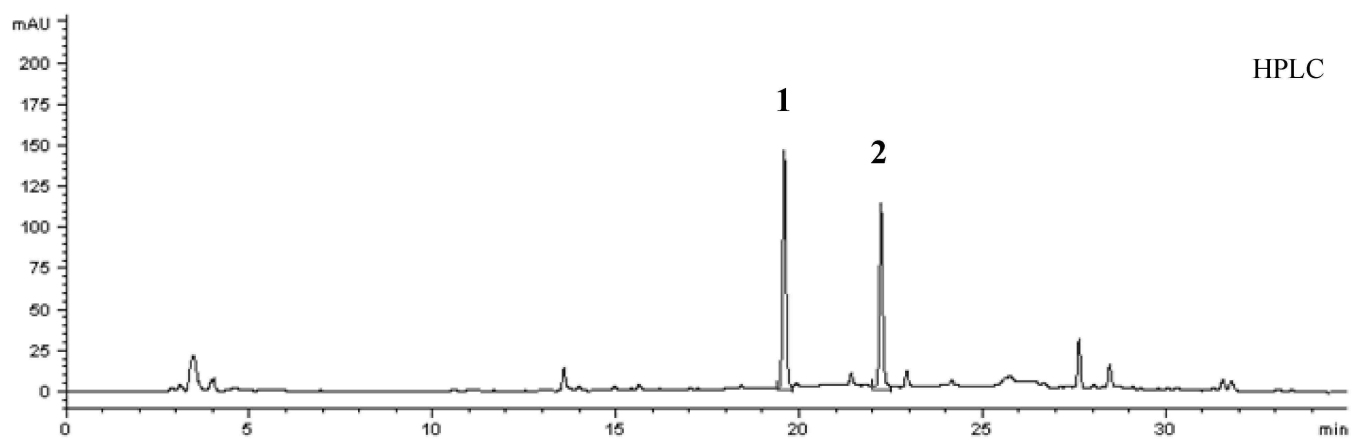

(b)
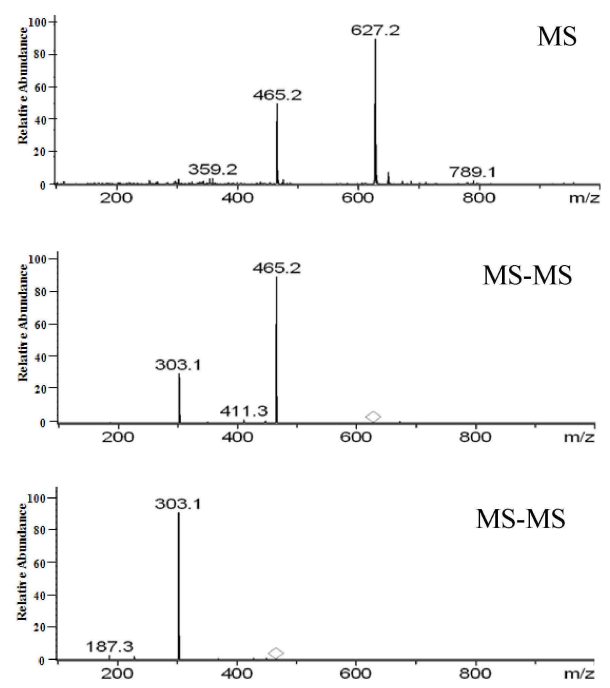

(c)
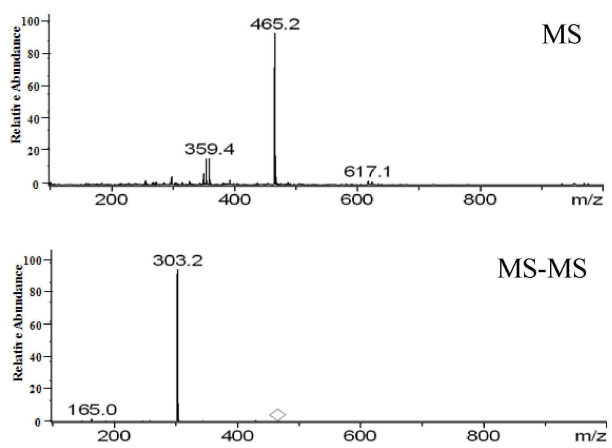

Fig. 1. HPLC spectrum of fresh onion extract (a), and positive ESI mass spectrum of compound 1 (b) and 2 (b). 1, quercetin-3,4'-O- $\beta$ $-D$-glucoside. 2, quercetin-4'- $O-\beta-\mathrm{D}^{-}$glucoside. $\diamond, \mathrm{m} / z$ of MS-MS fragmentation 
ing parameters were a capillary temperature of $250^{\circ} \mathrm{C}$, spray-needled voltage of $4.5 \mathrm{kV}$, and ES capillary voltages of $+3 \mathrm{~V}$ and $-47 \mathrm{~V}$ for positive and negative polarity, respectively. The sheath gas was nitrogen, at a flow rate of 50 arbitrary units. Mass analysis was carried out with a full-scan spectrum from 100 to $900 \mathrm{amu}$, in both positive and negative modes. Positive and negative MS-MS spectra were obtained by collision-induced dissociation (CID).

\section{Results and Discussion}

Aged black onion was made by aging process for 30 days at $60^{\circ} \mathrm{C}$ and high humidity $(90 \% \mathrm{RH})$. During the process, the fresh onion with white color was changed to black color.

The quercetin analogues (quercetin and quercetin glucosides) were assayed in onion bulbs before and after the aging process, using high performance liquid chromatography (Fig. 1a and 2b). In agreement with previous findings, indicating that onions contain both diglucosides and monoglucosides of quercetin, we found that the two major forms of quercetin in fresh onions were the diglucoside $(420 \mathrm{\mu g} / \mathrm{g}$ dry weight) and the monoglucoside (180 $\mu \mathrm{g} / \mathrm{g}$ dry weight). In aged black onions, however, the major form of quercetin was the aglycone (380 $\mu \mathrm{g} / \mathrm{g}$ dry weight). The result showed that the aging process of fresh onion increased the levels of quercetin, with concomitant reductions in $\mathrm{di}^{-}$and mono glucosides.

Mass spectral data confirmed the identities of quercetin and quercetin glucosides detected in onions (Fig. 1 and 2). In the positive ESI-MS spectra of fresh onion extract, peaks at $\mathrm{m} / z 627[\mathrm{M}+\mathrm{H}]^{+}$and $\mathrm{m} / z 465[\mathrm{M}+\mathrm{H}]^{+}$indicated the binding of two and one glycosyl moieties, respectively. In the positive ESI-MS spectra of aged black onion extract, a significant peak at $\mathrm{m} / 2303\left[\mathrm{M}+\mathrm{H}^{+}\right.$indicated the loss of two and one glycosyl moieties for comparison, the mass spectrum of a quercetin standard is presented (data not shown). The molecular ion $\mathrm{m} / z 303[\mathrm{M}+\mathrm{H}]^{+}$is the most abundant quercetin ion and ion $m / z 162[\mathrm{M}+\mathrm{H}]^{+}$is the value of one glycosyl unit. In addition, multiple reaction monitoring (MRM) of MS/MS showed that the characteristic ion transitions were from $\mathrm{m} / z 627$ (parent ion) to $\mathrm{m} / z 465$ (daughter ion) and from $\mathrm{m} / z 465$ (parent ion) to $\mathrm{m} / z 303$ (daughter ion) in fresh onion extract.

In conclusion, we demonstrated that the HPLC-ESI/ MS/MS technique constitutes an accurate and easy methodology for the qualitative and quantitative analysis of flavonoid in fresh onions and aged black onions. It allowed the identification of quercetin 3,4'-O-diglucoside and 4'-O-monoglucoside being the most abundant components in fresh onion and quercetin aglycone in aged black onion. These results indicated that the aging process of fresh onions for 1 month at $60^{\circ} \mathrm{C}$ resulted in complete deglycosylation of quercetin mono- and diglucosides present in fresh onions (Fig. 3). Such profiling is a rapid method that can be used to assess changes in the two major quercetin glycosides, occurring during the aging and blackening of onion bulbs.

(a)

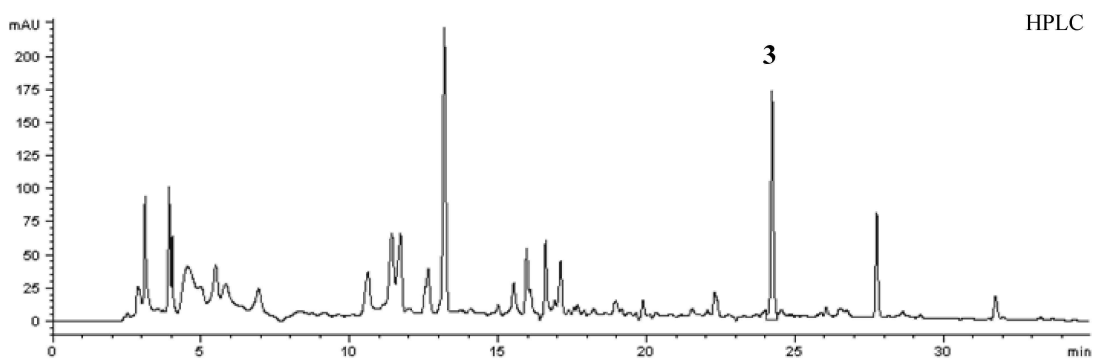

(b)

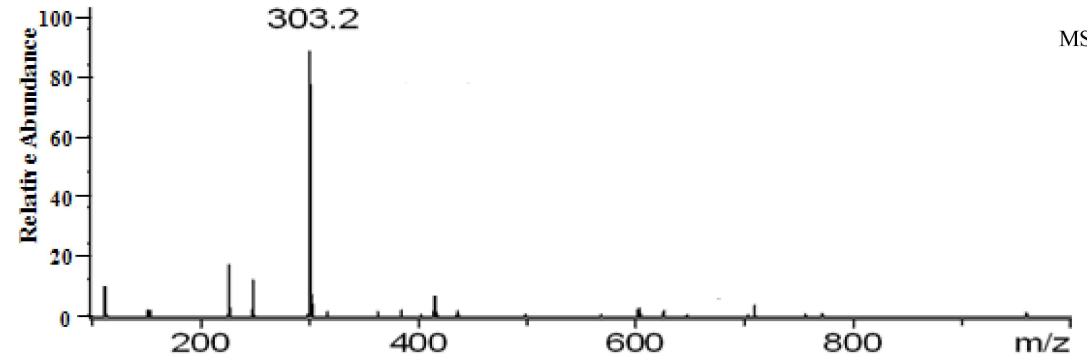

Fig. 2. HPLC spectrum of aged black onion extract (a) and positive ESI mass spectrum of compound 3 (b). 3, quercetin. 


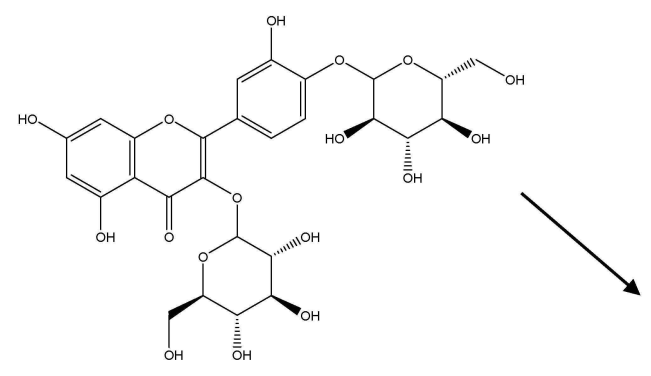

Quercetin-3,4'-O- $\beta$-D-glucoside
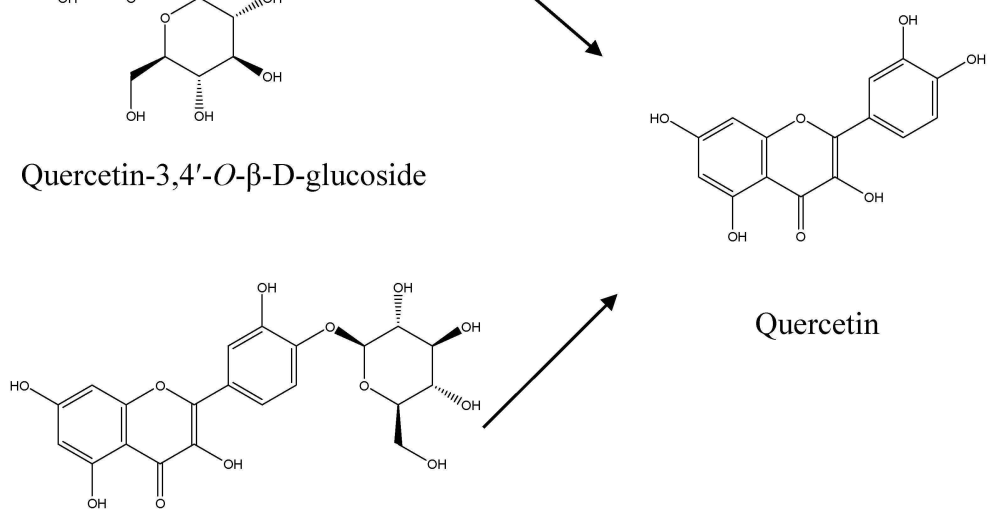

Quercetin

Quercetin-4'-O- $\beta$-D-glucoside

Fig. 3. Changes in the two major quercetin glycosides during the aging process of onion bulbs.

\section{References}

1. Bonaccorsi, P., C. Caristi, C. Gargiulli, and U. Leuzzi. 2008. Flavonol glucosides in Allium species: A comparative study by means of HPLC-DAD-ESI-MS-MS. Food Chem. 107, 1668-1673.

2. Cook, N. C. and S. Samman. 1996. Flavonoids-chemistry, metabolism, cardioprodective effects, and dietary sources. J. Nutr. Biochem. 7, 66-76.

3. Cuyckens, F. and M. Clays. 2004. Mass spectrometry in the structural analysis of flavonoids. J. Mass Spectrom 39, 1-15.

4. Fabre, N., I. Rustan, E. de Hoffman, and J. Quetin-Leclercq. 2001. Determination of flavones, flavonol, and flavanone aglycones by negative ion liquid chromatography electrospray ion trap massspectrometry. J. Am. Soc. Mass Spectrom 12, 707-715.

5. Hollman, P. C. H., J. M. P. van Trijp, M. N. C. P. Buysman, M. S. vd Gaag, M. J. B. Mengelers, and J. H. de Vries. 1997. Relative bioavailability of the antioxidant flavonoid querce- tin from various foods and plants. FEBS Lett 418, 152-156.

6. Merken, H. M. and G. R. Beecher. 2000. Measurement of food flavonoids by high-performance liquid chro- $^{-}$ matography. J. Agri. Food Chem. 48, 577-599.

7. Morihara, N., N. Ide, and N. Weiss. 2010. Aged garlic extract inhibits CD36 expression in human macrophages via modulation of the PPAR $\gamma$ pathway. Phytother Res 24, 602-608.

8. Price, K. P., J. R. Bacon, and J. C. Rodes. 1997. Effect of storage and domestic processing on the content and compo $^{-}$ sition of flavonol glucosides in onion (Allium cepa). J. Agri. Food Chem. 45, 938-942.

9. Slimestad, R., T. Fossen, and I. M. Vågen. 2007. Onions: a source of unique dietary flavonoids. J. Agri. Food Chem. 55, 10067-10080.

10. Wittig, J., M. Herderich, E. U. Graefe, and M. Veit. 2001. Identification of quercetin glucuronides in human plasma by high-performance liquid chromatography-tandem mass spectrometry. J. Chromatogr. 753, 237-243.

\section{초록 : HPLC-ESI/MS/MS를 이용한 생양파와 흑양파의 퀘세틴 배당체 분석}

\section{정동민 $^{1} \cdot$ 권선화 $^{1} \cdot$ 정영철 $^{2} \cdot$ 전효곤 $^{1}$ * $^{-1}$}

('한국생명공학연구원 전북분원 생물산업공정센터, ${ }^{2}$ 한국국제대학교 식품영양학과)

퀘세틴은 양파에 있는 주요한 플라보노이드이고, 항산화제 역할을 한다. 양파에 있는 퀘세틴은 주로 배당체 형태로 존재한다. 흑양파는 습도 $90 \%$ 와 온도 $60^{\circ} \mathrm{C}$ 조건 하에서 30 일 동안의 숙성처리과정으로 만들어진다. 흑양파 제조과정 전후의 양파 속에 있는 퀘세틴과 퀘세틴 배당체들은 HPLC-ESI/MS/MS를 이용하여 분석되었다. 생양파 속에는 퀘세틴 단당체와 퀘세틴 이당체가 동정되었고, 반면에 흑양파 속에는 퀘세틴만이 존재하였다. 그러한 결과들은 생양파에 있는 퀘세틴 배당체(단당체와 이당체)들은 숙성과정 동안 해당과정이 일어난다는 것을 의미한다. 이러한 분석프로파일은 숙 성과정 동안 발생되는 양파의 주요한 두 개의 퀘세틴 배당체들의 변화를 추정하는데 용이한 방법을 제공할 것이다. 